\author{
Katarzyna Majbroda \\ Katedra Etnologii i Antropologii Kulturowej \\ Uniwersytet Wrocławski \\ katarzyna.majbroda@uwr.edu.pl \\ ORCID: 0000-0001-5638-4240
}

\title{
ANTROPOLOGICZNE OTWARCIE NA POSTANTROPOCENTRYZM. SPRAWCZOŚĆ BYTÓW POZA-LUDZKICH W PROCESIE EKOLOGIZACJI WIEDZY
}

\section{Anthropological opening to post-anthropocentrism. The agency of non-human beings in the process of ecologisation of knowledge}

Streszczenie. Artykuł koncentruje się wokół otwarcia antropologii na postantropocentryzm oraz świat więcej-niż-społeczny w procesie ekologizacji wiedzy. Żyjemy w Antropocenie, nowej epoce geologicznej, w której działania człowieka wpływają na klimat, ekosystemy i środowisko jak nigdy przedtem. Tymczasem, dominujące rozumienie globalnej historii środowiska nie uwzględnia należycie jej powiązań z teorią społeczną, mimo że wątki te są nierozerwalnie związane ze społecznością i materialnością zmieniającego się świata ludzi i nie-ludzi. W ramach światowej antropologii społeczno-kulturowej przedstawiciele dyscypliny zajmują coraz bardziej zdecydowane stanowiska wobec zmian klimatycznych, rozwijając praktyki, które inwencyjnie można by nazwać 'ekologizacją antropologii' jako odpowiedź na tezę o przegrzaniu świata. Ruch konceptualnej transgresji kategorii 'człowiek', która jest podstawą antropocentrycznej wiedzy, może stać się dla antropologii szansą nie tylko na prognozowanie przyszłości społeczeństw, lecz także na wspóltworzenie wiedzy naukowej antycypującej i wyjaśniającej jej kształty.

Słowa kluczowe: Antropocen, ekologizacja wiedzy, Kapitalocen, postantropocentryzm, sprawczość, świat więcej-niż-społeczny. 
Abstract. The article focuses on the opening of anthropology to post-anthropocentrism, and the more-than-human world. We are living in the Anthropocene, a new geological era in which human activities are affecting climate, ecosystems and the environment like never before. However, the dominant understanding of the global environmental history does not adequately account for its connections to social theory, even though these themes are inextricably linked to the sociality and materiality of the changing world of humans and non-humans. Within the framework of the world's socio-cultural anthropology are being developed, and the representatives of the discipline are taking increasingly firm stances on climate change, developing practices that creatively can be called the 'ecologisation of anthropology' as a response to the notion that the world is overheated. A movement of conceptual transgression of the category 'human', which is the core of anthropocentric knowledge, can become an opportunity for anthropology not only to prognose the future of societies, but also to co-produce scientific knowledge anticipating and explaining its shapes.

Keywords: Anthropocene, ecologisation of knowledge, Capitalocene, post-anthropocentrism, agency, more-than-social world.

\section{Wprowadzenie}

Wydaje się, że jednym z podstawowych wyzwań, jakie stawia przed naukami społecznymi i humanistyką kryzys klimatyczny oraz wzrastająca świadomość ekologiczna, jest rekonceptualizacja kategorii rzeczywistości społecznej, a także kluczowych dla tych nauk pojęć, takich jak człowiek i społeczeństwo. Pilnym wyzwaniem jest również ekologizacja wiedzy i perspektyw badawczych wymagająca intensywnej pracy wyobraźni na poziomie ontologicznym, epistemologicznym i metodologicznym. Antropologia jako dyscyplina, w której nazwie rdzeniem jest anthropos, staje aktualnie przed wyzwaniem uwzględnienia w swych perspektywach i analizach transrelacyjnej architektury rzeczywistości oraz sprawczości 
bytów poza-ludzkich. Trudno oczekiwać, że antropologia doświadczy dogłębnej transformacji wedle osi postantropocentryzmu, w pełni angażując się w tzw. postludzki zwrot. Jednak jako dyscyplina żywo reagująca na aktualne wydarzenia i procesy w skali globalnej i lokalnej, katastrofy ekologiczne i środowiskowe oraz ich społeczne skutki, rozwija swoją wyobraźnię naukową i instrumentarium badawcze w ścisłych relacjach ze społecznością i materialnością zmieniającego się świata ludzi i nie-ludzi. Nowe perspektywy postrzegania rzeczywistości w trans-zależnościach, splotach i asamblażach wyostrzają potrzebę wyraźnego usytuowania się antropologów i antropolożek w tych dynamicznych, ludzko-nie-ludzkich aranżacjach i nowych ekonomiach wiedzy.

Zanurzenie w heterogenicznej, wielogatunkowej rzeczywistości jest fascynującym, ale i wymagającym poznawczo doświadczeniem. Funkcjonowanie społeczeństw w wysoce zglobalizowanym świecie, coraz wyraźniej powiązanym politycznie, ekonomicznie i technologicznie uświadamia nie tylko konieczność pogłębiania wiedzy na temat globalnych zależności, lecz także zaświadcza o konieczności przemyślenia i redefinicji najbardziej podstawowych ram konceptualnego ujmowania rzeczywistości. Ustanowienie epoki Antropocenu jako czasu wyrazistej sprawczości geologicznej gatunku ludzkiego (Crutzen, Stoermer 2000: 17-18), który funkcjonuje w świecie wielogatunkowego sąsiedztwa i ludzko-nie-ludzkich sojuszy, zachęca do tego, by rozwijać pogłębione refleksje wokół tradycyjnych sposobów postrzegania rzeczywistości jako bytu społeczno-kulturowego. Wydaje się, iż jest to jedno z pilniejszych wyzwań stawianych przed współczesnymi naukami społecznymi i humanistyką. Wyzwanie to podjęto już jakiś czas temu w antropologii społeczno-kulturowej, której ambicją jest nie tylko rozumienie i wyjaśnianie obserwowanych procesów i zjawisk, lecz także inwencyjne reagowanie na aktualne wyzwania płynące z relacyjnego współbycia ludzi i bytów poza-ludzkich w określonych kontekstach środowiskowych, materialnych, technologicznych, kulturowo-społecznych i geopolitycznych (Ingold 2013; Eriksen 2016; (Hastrup, Skrydstrup 2013). 
Ruch konceptualnego przekroczenia kategorii ‘człowiek' będącej fundamentem gmachu antropocentrycznej wiedzy nie jest, rzecz jasna, pomysłem nowym. Myślenia postantropocentrycznego można by doszukiwać się w mitologiach świata, rozmaitych wierzeniach i legendach oraz we właściwych kulturze tradycyjnej holistycznych ujęciach rzeczywistości, których istotą jest koincydencja ludzi i bytów poza-ludzkich: fauny, flory (Moszyński 1958) oraz istot nadprzyrodzonych (Tomicki, Tomicka 1975). Trudno byłoby jednak wywieść współczesne myślenie postantropocentryczne $\mathrm{z}$ uniwersum kultury tradycyjnej nie tylko ze względu na powierzchowność rzekomych podobieństw, lecz także z uwagi na wyraźne lokowanie w nim człowieka w centrum otaczającego go mikroświata.

Coraz wyraźniejsza w ostatnich dekadach potrzeba reinterpretacji i ponownego przemyślenia kategorii fundacyjnej dla nowożytnej humanistyki nabiera poznawczej wyrazistości wraz z refleksją posthumanistyczną, tzw. ontologią relacyjną, humanistyką środowiskową, environmental studies, etnografią wielogatunkową, głęboką ekologią, studiami nad nauką i technologią (STS), teorią aktora-sieci (ANT). Wszystkie te nurty przekraczają tradycyjnie pojęty antropocentryzm a wraz z nim lokowanie kategorii człowieka i tego, co ludzkie na szczycie hierarchii bytów i wartości oraz w centrum poznania. W swym krytycznym usytuowaniu wobec antropocentryzmu, proponują nowe onto-epistemologie, które dynamizują i komplikują zjawiska i procesy, dostrzegając w tych aranżacjach sprawczość bytów poza-ludzkich. Wpisane w nie perspektywy oglądu rzeczywistości wyzyskują przy tym dla refleksji naukowej sieci zależności, w jakie uwikłane są podmioty ludzkie i poza-ludzkie, zjawiska naturalne, procesy, a także byty technologiczne oraz materialne.

To wyjście poza człowieka zmienia nasze rozumienie podstawowych pojęć analitycznych, takich jak kontekst, ale także innych, takich jak reprezentacja, relacja, jaźń (...), życie, rzeczywistość, umysł, osoba, myśl, forma, finanse, przyszłość, historia, przyczyna, sprawczość, hierarchia i ogólność. Zmienia się to, co rozumiemy przez te terminy i to, gdzie lokujemy zjawiska, do których się odnoszą, jak również nasze rozumienie skutków, jakie te zjawiska wywierają w świecie, w którym żyjemy (Kohn 2013: 22-23). 
Perspektywa postantropocentryczna pojawiła się w nauce, w ostatnich trzech dekadach XX w. na fali wzmożonego zainteresowania kryzysami środowiskowymi i ekologicznymi oraz ich społeczno-ekonomicznymi skutkami. Trudno oprzeć się wrażeniu, że nurty poznania, które umownie - i w pewnym esencjalistycznym uproszczeniu - można by określić jako relacyjne, pojawiły się w wyobraźni naukowej w odpowiedzi na coraz trudniejsze do przeoczenia, niepokojące konsekwencje urbanizacji i uprzemysłowienia życia, wzmożonej eksploatacji surowców, zanieczyszczenia powierza, wysokiej emisyjności metanu oraz CO2. Jak trafnie zauważa Claire Colebrook, „Antropocen wydaje się nadchodzi dokładnie w momencie, gdy cała nowa seria materializmów, witalizmów, realizmów i nieludzkich zwrotów wymaga od nas myślenia o tym, co ma konkretny i mocny byt niezależnie od naszego poczucia świata" (Colebrook 2017: 3).

W takiej perspektywie postrzega idee posthumanizmu również Francesca Ferrando, podkreślając, że ich istotą jest koncentracja „na decentralizacji pozycji ludzkiego czynnika jako prymarnego punktu dyskursu" (Ferrando 2016a: 23). Posthumanizm jawi się w refleksji filozofki jako wyrazista etyka spleciona $z$ troską o aktualny i przyszły stan środowiska i szerzej, całej planety. Reinterpretacja kategorii człowieka i ukazanie go w sieciach współzależności z bytami poza-ludzkimi może być zatem poczytywana jako działanie w nurcie krytycznej troski o przyszłość świata, a zatem również człowieka. Taką wykładnię rozwija Ferrando, wskazując na pilną potrzebę uświadomienia gatunkowi ludzkiemu, że nie jest autonomicznym, wyabstrahowanym od otoczenia bytem, ale funkcjonuje jako „węzłowy punkt odniesienia wobec ekosystemu”. Tylko w taki sposób, możemy uświadomić sobie, że ,dewastowane środowisko negatywnie wpływa również na kondycję ludzką" (Ferrando 2016b: 245).

\section{Przemyśleć naturę na nowo}

Pogłębiający się kryzys klimatyczny, powiązany z rozwojem nowoczesnych technologii, eksploatacją zasobów naturalnych i wykorzystaniem energii paliw kopalnych (Srivastaw 2019: 111-149), grożący utratą 
przyszłości (Bińczyk 2018), spowodował konkretne zmiany w myśleniu i praktykach ludzi na całym świecie, kształtując aktualne polityki zielonego ładu, zrównoważonego rozwoju (Evans, Abrahamse 2009; Connolly, Prothero 2008: 117-146) oraz transformacji węglowej i energetycznej (Boyer 2019). Wzrastająca świadomość ekologiczna wpływa na formułowanie postulatów deep ecology (Bombik 2020) oraz sprawiedliwości środowiskowej (environmental justice) (Steger 2007; Hornborg 2019). Wraz z upowszechnianiem się wiedzy o negatywnym wpływie współczesnych kryzysów na dobrostan ludzi i planety zmienia się wyraźnie sposób postrzegania rzeczywistości oraz wyjaśniania trybów i zasad jej funkcjonowania. Przemyśleniom i reinterpretacjom podlega również relacja natury i kultury. Do niedawna dychotomiczne ujęcie tych dwóch przestrzeni rzeczywistości stanowiło konceptualne wsparcie dla myślenia o naturze w kategoriach nieznaczącego tła, rodzaju scenerii, w której rozgrywają się zjawiska i procesy kulturowe. Posthumanistyczna krytyka tradycyjnie pojętego humanizmu oraz powiązanych z nim hierarchii bytów i wartości wiązała się ze swoistą rewitalizacją kategorii natury, która, postulatywnie i dyskursywnie, odzyskała swoją sprawczość, stając się istotnym elementem procesów środowiskowych, ekonomicznych i politycznych, co znalazło swój wyraz np. w koncepcji naturokultury Donny Haraway. Filozofka zakumulowała w tej kategorii ontologiczną relacyjność obu domen, polegającą na tym, że wespół stanowią konceptualne, wzajemnie się konstytuujące części rzeczywistości w wieloaspektowym uwikłaniu jednej w drugą (Haraway 2012).

Ze wspomnianym przemyśliwaniem kategorii natury wiąże się nowy sposób konceptalizowania podmiotu ludzkiego, coraz częściej sytuowanego w sieciach relacji z kulturą, środowiskiem oraz otoczeniem fizycznym (Braidotti 2014; Hayward 1997). W antropologicznych, zaangażowanych ekologicznie, perspektywach poznania środowisko to nie tylko przyjazna przestrzeń funkcjonowania człowieka, lecz coraz częściej obszary przekształcone i zdewastowane przez człowieka; skażone wody i gleby, zanieczyszczone powietrze, energokrajobrazy (energyscapes) (Smith, High 2017: 7), industrialne i postindustrialne pejzaże (Fortun 2001). Wszystkie te przestrzenie stanowią potencjalne pola badawcze, w ramach których rozwijana jest antropologiczna praxis pośród praktyk z porządku natury, 
kultury, ekonomii i technologii. W optyce tych nurtów badawczych dostrzegane są „niepokoje przemysłowe” (Penty 2018), a eksploatacja natury jest widziana jako szczególna egzemplifikacja wyzysku industrialnego. Pojawienie się w naukach społecznych i humanistyce relacyjnych perspektyw postrzegania kultury, natury, ludzi, bytów biotycznych i abiotycznych (Bakke 2020: 165-185), technologicznych oraz materialnych jest wyrazem poszukiwania remedium na pojmowanie natury jako biernego rezerwuaru zasobów, np. węgla, gazu ziemnego, ropy naftowej oraz wiązki usług ekosystemowych, które dominuje w kapitalistycznej optyce oraz w neoliberalnych dyskursach zarządzania środowiskiem (Castree 2018; Duit 2016). W pisany w filozofię neoliberalną projekt ekonomiczny oraz jego implikacje dla stosunków społecznych, politycznych i kapitałowych remodelują także rozumienie środowiska i przyrody oraz strategie zarządzania nimi (McCarthy, Prudham 2004: 276-278). Wpływają przy tym na lokalną wyobraźnię środowiskową ludzi żyjących w różnych częściach świata (Buell 1995; Yusoff, Gabrys 2011).

Wydaje się zatem, że wprowadzanie do dyskursów historii środowiska kontekstów społeczno-kulturowych pozwala na wzmocnienie tradycji powiązań przeobrażeń środowiska $\mathrm{z}$ teorią społeczną, otwierając ją na byty poza-ludzkie. Wyraźnie wyartykułował to rozpoznanie Alf Hornborg, podkreślając, że „dopóki sposoby, za pomocą których natura i społeczeństwo przenikają się w naszych artefaktach będą źle rozumiane; albo przez utrzymywanie ich w ontologicznej izolacji lub przez znoszenie analitycznego rozróżnienia między nimi, żadne $\mathrm{z}$ tych dwóch podejść nie zdoła uchwycić dylematu Antropocenu" (Hornborg 2019: 11). Podkreślane przez antropologa konceptualne odróżnienie natury od społeczeństwa stanowi zabieg strategiczny, który jego zdaniem, jest konieczny w sytuacji, gdy „musimy zachować naszą zdolność do analitycznego rozróżniania między symbolicznymi i biofizycznymi aspektami procesów socjoekologicznych”. Jeśli mamy ambicje, „by regulować globalną polaryzację społeczną i zmiany środowiskowe, musimy przekształcić artefakty, które generują te procesy"(Hornborg 2019: 192).

Świadomość procesów dyskursywnych i społeczno-kulturowych zależności, które współtworzą kategorię natury oraz kontekstów jej 
rozumienia i wartościowania wydaje się szczególnie ważna w obliczu dynamiki Antropocenu, rozwijających się nurtów tzw. zrównoważonego rozwoju, projektów transformacji energetycznych prognozujących zielone, post-emisyjne przyszłości. Koncepcja świata natury jako obojętnej, biernej rezerwy zasobów, niemającej wpływu na procesy społeczne i kulturowe jest trudna do utrzymania w kontekście coraz intensywniejszych dyskusji wokół sprawczości bytów poza-ludzkich i jej społecznych oraz ekologicznych konsekwencji. Dylematy oświetlane przez dyskusje wokół kryzysu klimatycznego, Antropocenu i Kapitalocenu sprawiają, że zaczynamy myśleć strategicznie relacyjnie i asamblażowo, co wiąże się z przesunięciem perspektywy i uznaniem świata w jego ontologicznej złożoności.

\section{Świat więcej-niż-ludzki, rzeczywistość więcej niż-społeczna}

Rzeczywistość więcej-niż-społeczna to synonim rzeczywistości empirycznej, a tym samym nie jest kategorią wydumaną i abstrakcyjną. Ludzie posiadają, rzecz jasna, niepowtarzalne w żadnym innym gatunku własności, przywileje i umiejętności, a w wielu obszarach życia zachodzą niepowtarzalnie ludzkie procesy społeczne, lecz większość z nich odsłania iluzoryczność wyłącznie antropogenicznego wymiaru kultury i społeczeństwa. Coraz wyraźniej obecna w dyskursach nauk społecznych i humanistycznych kategoria świata więcej-niż-ludzkiego (more-than-human world) (Puig de la Bellacasa 2017; Pyyhtinen 2016; Bastian, Jones, Moore, Roe 2016) pojawia się także coraz śmielej w polskim dyskursie naukowym, choć zdarza się, że budzi kontrowersje oraz obawy etyczne. Mimo iż antropologia społeczno-kulturowa jest dyscypliną o wyostrzonej uwadze społecznej i zmyśle szybkiego reagowania na aktualne problemy i wyzwania współczesności, bywa, że jej wyobraźnia nasyca się nowymi kategoriami i pojęciami ostrożnie i powoli.

Idea konceptualnego przekroczenia antropocentryzmu w poznaniu odczytywana w literalny sposób jest dla antropologów i antropolożek kłopotliwa, ponieważ wymaga od dyscyplinowego imaginarium wyobrażenia 
sobie sytuacji, w której rezygnujemy z myślenia o świecie wyłącznie w perspektywie ludzkiej uznanej za uprzywilejowaną, przeformułowując fundamentalne kategorie i założenia, na których wsparta jest konceptualnie nowożytna humanistyka, a także wieloletnia tradycja antropologicznego postrzegania i badania rzeczywistości. Być może obserwowana nieufność wobec kategorii świata więcej-niż-ludzkiego wynika z pewnej „abstrakcyjnej niespecyficzności”, a także z przekazu etycznego, „który zachęca nas do przekroczenia tego, co »ludzkie«, na rzecz czegoś »więcej niż «" (Puig de la Bellacasa 2017: 1-2). Jednak mimo iż ta kategoria powstała, by wymknąć się tradycyjnemu myśleniu humanistycznemu, a zatem centralnie usytuowanemu podmiotowi ludzkiemu, paradoksalnie, człowiek i to, co ludzkie pozostają w jej centrum, stanowiąc punkt wyjścia dla ontologicznych i epistemologicznych przekroczeń. Wbrew obawom o marginalizację człowieka i odmawianie mu naczelnych zdolności poznawczych, sprawstwo ludzkie ma się w tej koncepcji całkiem dobrze w myśl trafnej uwagi Lucy Suchman, która podkreśla, ,że kiedy angażujemy się w technonaukowe asamblaże, ceną za uznanie sprawczości artefaktów nie musi być zaprzeczenie naszej własnej" (Suchman 2007: 285). Współbrzmiąca z nią antropolożka Clare Colebrook zaznacza z kolei, że „pytanie o to, co jest inne lub poza-człowiekiem jest »definitywnie« ludzkie, gdyż człowiek od zawsze był opisywany przez odrzucenie jakiejkolwiek normatywnej definicji" (Colebrook 2015: 218).

Jednym z nośnych poznawczo nurtów, w ramach którego podejmowane są próby transwersalnych przekroczeń tej fundacyjnej dla nowożytnej nauki i filozofii kategorii jest wspominany już posthumanizm, opracowująca jego dyskursywne i badawcze wykładnie posthumanistyka oraz krytyczna teoria posthumanistyczna rozwijająca się „między izmami post-ludzkimi z jednej strony, a post-antropocentryzmem z drugiej" (Braidotti 2018: 339). Posthumanistyka obejmuje swoją nazwą określone koniektury myślowe, które od wczesnych lat 80 . XX w. pojawiały się naukach społecznych i humanistycznych w publikacjach fundatorów tzw. nowej relacyjnej ontologii i powiązanej z nią antropologii laboratorium (Latour, Woolgar 2000; Knorr-Cetina 1981). W swej skrystalizowanej formie stanowi nie tyle odrębny jednowątkowy nurt poznania, ile przede wszystkim splot 
wielu pojęć, propozycji teoretycznych i kategorii (Holbraad, Pedersen 2017), a także krytyk tradycyjnie pojętej humanistyki, które wypracowywane są w nurtach proekologicznej, środowiskowej humanistyki oraz w innych aktualnie klarujących się perspektywach badawczych, jak np. etnografia transrelacyjna (zob. Majbroda 2021a, 2021b).

Wszystkie te propozycje sięgają do różnych koncepcji filozoficznych i mają swoje określone genealogie, jednak widziane jako splot różnic i podobieństw stanowią pewną dynamiczną propozycję nie tylko epistemiczną, lecz także światopoglądową i polityczną. Zdaniem Rosi Braidotti, ich „,zbieżność w krytycznej myśli postludzkiej wytwarza łańcuch teoretyczny, społeczny i polityczny, który jest czymś więcej niż sumą swoich części i wskazuje na jakościowy skok w nowych orientacjach konceptualnych" (Braidotti 2018: 339). Wspomniane nurty i perspektywy stanowią propozycje odpowiedzi na aktualne wyzwania klimatyczne, środowiskowe i społeczno-ekonomiczne formułowane w różnych miejscach na świecie. Relokacja kategorii człowieka z centrum refleksji naukowej na relacyjne sieci współzależności stanowi według ich założeń, konceptualny ruch poczytywany jako wyraz krytycznej troski o przyszłość świata, a zatem również gatunku ludzkiego. Centralne umiejscowienie nas - ludzi - podmiotów w procesie poznania nie ulega tu w zasadzie radykalnym krytykom, zmienia się natomiast sposób rozumienia i wartościowania tej pozornie uprzywilejowanej pozycji. Jeśli przyjmiemy, że humanizm to szeroko zakrojona postawa kulturowa, powstała w Europie w XV i XVI w., która podkreśla patos ludzkiej egzystencji i celebruje człowieka jako myśliciela, twórcę i uprzywilejowanego aktora życia społecznego, postantropocentryzm można by zobaczyć jako perspektywę lokowania konkretnych ludzi w relacjach ich różnic i podobieństw oraz w sieciach współbycia i współdziałania z bytami poza-człowiekiem, które kształtują jego podmiotowość psychofizyczną, wpływając na dobrostan, wywołując określone emocje i afekty.

Konceptualne i badawcze przekraczanie binaryzmów i stratyfikacji ustanowionych $\mathrm{w}$ tradycyjnych nurtach wiedzy wiąże się z potrzebą reorientacji myślenia na takie, które zamiast hierarchicznego porządkowania różnych elementów rzeczywistości, uprzywilejowuje relacyjne ich funkcjonowanie, kierując uwagę badawczą na przyczyny, konteksty 
i konsekwencje tych wielorakich połączeń dla świata więcej-niż-społecznego. Szukając wykładni dla tego rozpoznania, warto zwrócić się w stronę filozofii Gillese'a Deleuze'a, który czerpiąc inspirację z rozważań Davida Hume'a przekonuje, iż podmiot jest ukształtowany przez przedsubiektywne elementy połączone ze sobą siecią relacji (Deleuze 2001: 65-66). W podobny sposób rozważa miejsce człowieka w świecie i jego usytuowanie w procesie poznania Michele Serres w Le contract naturelle (1992), proponując zobaczenie człowieka nie tyle w kategoriach samowiednego, sprawczego podmiotu, który w intencjonalny sposób podejmuje działania przekształcające naturę, podbijając ją i ujarzmiając, ile jako element świata natury, jako formę życia, która w procesie poznania uświadamia sobie własne usytuowanie w naturze oraz w relacjach z nią i wobec niej. Co więcej, w myśl filozofa, wiedza jaką rozwijamy, to w gruncie rzeczy wiedza o naszym usytuowaniu w świecie powiązań i współzależności obiektów, zjawisk oraz procesów (Serres 1992). Do podobnych wniosków dochodzi Robert Pepperell w The Posthuman Manifesto, podkreślając, że trudno wnioskować o otoczeniu zewnętrznym wobec człowieka, w sytuacji, gdy nie sposób ustalić zakresu tej kategorii. „Gdy przyjmiemy do wiadomości, że umysł i ciało nie mogą być całkowicie rozdzielone, a ciało i środowisko nie mogą być zupełnie odseparowane, to pozostanie nam pozornie absurdalny, ale logicznie spójny wniosek, że świadomość i środowisko nie mogą być absolutnie odrębne" (Pepperell 2005: 11).

Konieczności racjonalnego wyjaśniania wzajemnych wpływów i relacji ludzi oraz środowiska wiąże się z potrzebą ponownego namysłu nad kategorią 'społeczeństwo', co od pewnego czasu, m.in. za sprawą Bruno Latoura proponującego w zamian usieciowiony kolektyw, nie wydaje się już większą kontrowersją (Latour 2010). Potrzeba ta nie wiąże się z procesem naturalizowania technologii lub stechnicyzowania środowiska, lecz z dostrzeganą w naukach społecznych koniecznością wprowadzenia refleksji o bytach, zjawiskach i procesach poza-ludzkich do teorii społecznej, by uczynić ją lepiej przygotowaną na wyzwania poznawcze płynące z rzeczywistości empirycznej.

Słuszność ma filozofka feminizmu korporalnego Elisabeth Grosz, przypominając, iż „to, co ludzkie znajduje się pod konceptualnym obstrzałem 
od czasu pojawienia się tak zwanej filozofii postmodernistycznej, która przede wszystkim uczyniła z człowieka raczej rezultat historii, języka i polityki aniżeli ich przyczynę" (Roffe, Stark 2015: 19). W pewnym sensie wypracowane $\mathrm{w}$ ramach posthumanizmu podejście postantropocentryczne koresponduje z poststrukturalistycznymi i postmodernistycznymi diagnozami przekroczenia człowieka jako bytu współzależnego, konstruowanego w procesach i relacjach wiedzy i władzy oraz w sieciach dyskursów. Jednak cel tych konceptualnych przekroczeń podmiotu ludzkiego jest zgoła inny. Nie idzie tu bowiem o zaznaczenie ludzkiego uwikłania w dyskursywne strategie bycia i gry językowe, lecz o o zmianę sposobu postrzegania rzeczywistości dotąd kategoryzowanej z pozycji centralnie sytuowanego podmiotu znajdującego się $\mathrm{w}$ uprzywilejowanej pozycji ontologicznej. Jak podkreśla Theodore Schatzki, ,posthumanistyczna nieufność wobec tego, co ludzkie", podobnie jak uznanie nie-ludzi za współtowarzyszy życia społecznego, ,jest ważnym krokiem w rozwoju intelektualnym, z którym analizy życia społecznego muszą się pogodzić". Filozof podkreśla jednak, że ,posthumaniści nie mają racji, obalając integralność, wyjątkowe bogactwo i znaczenie ludzkiej sprawczości”(Schatzki 2002: XV). Jednocześnie pojawia się przekonanie, iż:

ludzka interwencja nie znika, ale sprawczość zostaje rozproszona. Interesy $i$ inne afektywnie ożywione siły - takie jak troska i opie$\mathrm{ka}$ - zostają zdecentrowane i rozproszone w polach materialności tworzących znaczenie: zamiast być umiejscowionymi w intencjonalności ludzkiej podmiotowości, zaczynają być rozumiane jako głęboko uwikłane w ciągłe materialne przekształcanie świata (Puig de la Bellacasa 2017: 31).

Powyższa myśl znajduje rozwinięcie w nurtach nowych materializmów, np. w zaproponowanym przez Karen Barad pojęciu 'intra-akcji', które w przeciwieństwie do zwykłej 'interakcji’ zakładającej uprzednie istnienie niezależnych bytów/relacji, stanowi głęboką zmianę konceptualną w myśleniu o „byciu w rzeczywistości”. To właśnie poprzez sprawcze intra-akcje granice i cechy elementów współtworzących zjawiska 
rzeczywistości nabierają swoistości (Barad 2003: 815). Jak powiada filozofka, ,świat jest intraaktywnością w swym zróżnicowanym materializowaniu" (2003: 817). Symetryczne postrzeganie relacji badacz-rzeczywistość oraz zmiana w usytuowaniu poznającego podmiotu relokowanego z centrum obserwacji na sploty wielorakich zależności, może budzić pewne obawy, a z pewnością pytanie o prawomocność, czy inaczej mówiąc, o czynniki legitymizacji wiedzy, która w ramach tej perspektywy powstaje. Wiedza naukowa, nawet ta powstająca w doświadczeniu, głębokim uczestnictwie, zaangażowaniu i sensorycznym zanurzeniu $\mathrm{w}$ świecie, potrzebuje bowiem pewnego dystansu pomiędzy sytuacją egzystencjalną i sytuacją badawczą. Jej kształty nabierają ostrości w pewnym „,pomiędzy" zapośredniczonym przez doświadczenia empiryczne, określone koncepcje teoretyczne, kategorie analityczne i badawcze, które kształtują wyobraźnię badacza i badaczki. Nie jest to jednak, co wymaga podkreślenia, kontynuacja Sokratejskiej koncepcji poznania możliwego dzięki pracy wyabstrahowanego ze świata, czystego intelektu, bowiem wiedza o tym, co aktualne, wymaga zanurzenia w świecie i zdecydowanego przekroczenia tzw. kontemplacyjnego modusu poznania, o czym w polskiej humanistyce zajmująco piszą, np. Ewa Rewers (2017: 73-74)i Ewa Domańska (2007: 55-57). To nieustanne „dzianie się” rzeczywistości w sensie ontologicznym i epistemologicznym podkreśla również Barad, przekonując, że „materia nigdy nie stanowi materii raz na zawsze ustanowionej. Cechuje ją bowiem radykalne otwarcie" (Dolphijn, Van der Tuin 2018: 57). Podobne rozpoznanie formułuje María Puig de la Bellacasa, podkreślając, iż współcześnie ,stało się bezsporne, jeżeli kiedykolwiek było, że w czasach powiązania nauk technicznych z naturokulturami, byt i losy tak wielu rodzajów i gatunków na tej planecie są nieuchronnie splecione" (2017: 1).

Co więcej, jak przekonują Donna Haraway (2012) i Schatzki (2002) tym, co wymaga aktualnie refleksji nie jest kategoria człowieka sama w sobie, lecz poszerzenie rozumienia kategorii sprawczości w taki sposób, by analizy społeczne mogły uwzględnić wielorakie działania podmiotów i obiektów więcej-niż-ludzkich oraz ich przebiegi i konsekwencje wpływające na życie społeczne. Podobna myśl pojawia się również 
w rozważaniach Margaret Archer, która mimo uprzywilejowania w procesie sprawczości człowieka w jego refleksyjnej mowie wewnętrznej i świadomym usytuowaniu w świecie względem własnych trosk, możliwości i nadziei (Archer 2013), zaznacza, iż: „należy podkreślić (co do niedawna nie byłoby wcale konieczne), że świat to coś więcej niż społeczeństwo”, a „relacje z naturą stanowią transcendentalny warunek bycia człowiekiem" (Archer 2013: 26). Eksponowane przez filozofkę relacje człowieka ze światem są nie tylko źródłem świadomości, lecz także autorefleksyjności, która wyróżnia gatunek ludzki. Podkreślenie relacyjnego wymiaru kształtowania się autorefleksji zawsze w odniesieniu do siebie, w relacji do i wobec świata, zarówno naturalnego, jak i materialnego/technologicznego, wydaje się szczególnie ważne w sytuacji, gdy praktykujemy antropologię wśród natury, przedmiotów, artefaktów, maszyn, w świecie technologii i materii.

Tym tropem myślenia podąża Tim Ingold, rozwijając swój projekt antropologii środowiskowej, przekonując, że pojęcie „aktora” i „sprawstwa” wynikają z tzw. logiki ucieleśnienia stanowiącej fałszywą przesłankę, według której sprawczość jest czymś posiadanym przez ludzi, podczas gdy, zdaniem antropologa, jest wynikiem zanurzenia człowieka w działaniu (Ingold 2013: 96-97). Antropolog w celu podkreślenia procesualności i działania, które wpisane są $w$ człowieczeństwo, inspirując się $\dot{z y}$ jacym w XIII w. filozofem i teologiem Rajmundem Llullem, który określił człowieka zwierzęciem człowieczącym - Homo est animal homificans wprowadził nazywający ten proces czasownik: homificare. „Człowiek człowieczy samego siebie, innych ludzi, królestwo zwierząt i roślin, a w istocie cały wszechświat", pisze w ślad za filozofem Ingold, kierując uwagę na będący w ruchu modus, w jaki „dzieje się” życie, podkreślając tym samym, że kondycja ludzka ma ontologicznie relacyjny charakter współtworzony w zależnościach i współbyciu człowieka z szeroko rozumianym otoczeniem zewnętrznym (Ingold 2013: 97).

Ten zdroworozsądkowy i potoczny w gruncie rzeczy sposób postrzegania i rozumienia rzeczywistości nie zawsze jednak znajdował swoje odzwierciedlenie w strategiach jej poznawania i diagnozowania. Na różne sposoby nazywane i kategoryzowane, choć zwykle nieuprzywilejowywane 
w poznaniu: powietrze, atmosfera, klimat, substancje chemiczne, pestycydy (Fortun 2001), odpady postprodukcyjne, różnego rodzaje ciecze i substancje będące ubocznymi efektami maszynerii produkcyjnej, wytwórstwa, wydobywania złóż i ich obróbki (zob. Jones, Rigby, Williams 2020), ale także woda, ziemia, skały, temperatura (Hastrup, Skrydstrup 2013; Dove 2014), materia, technologie, narzędzia, dyskursy - wszystkie te elementy warunkują i dookreślają wiele spośród zjawisk i procesów od dekad analizowanych w ramach antropologii i innych nauk społecznych, choć w odmiennych ramach konceptualnych.

W powyższych i wielu im podobnych rozważaniach czyni się starania, by zdynamizować kategorię 'człowiek', wprawiając ją w ruch w toku stawiania pytań o jego sprawczość, ograniczenia psychofizyczne, możliwości kognitywne, rozwijane praktyki społeczne, wartości w powiązaniach i zależnościach z tym i wobec tego, co poza-ludzkie. Jednocześnie w narracjach wokół Antropocenu klaruje się wyraźna tendencja do esencjalizowania gatunku ludzkiego jako geologicznej siły sprawczej, która w znacznym stopniu odpowiada za kryzys klimatyczny i środowiskowy oraz aktualną kondycję planety. Dyskursom epoki po holocenie nie zawsze towarzyszy refleksja o zróżnicowaniu ludzi ze względu na ich cechy, miejsce do życia na konkretnym kontynencie, kapitał społeczny i ekonomiczny, sprawczość geopolityczną, prawa i przywileje, dostęp do edukacji, udział w eksploatacji zasobów naturalnych, dostęp do dóbr ekonomicznych i symbolicznych. Zwykle w rozważaniach o nowej epoce nie problematyzuje się czynników, które w skuteczny sposób uniemożliwiają unifikację ludzkości ,jako takiej”. Ze wspomnianymi praktykami esencjalizacji i strategicznej homogenizacji gatunku ludzkiego wiąże się zjawisko dystrybucji ludzkiej/społecznej odpowiedzialności za stan i przyszłość planety, w którego oglądzie nie sposób przeoczyć, że „,dominująca narracja zwolenników Antropocenu tworzy abstrakcyjną ludzkość, jednakowo zatroskaną, czyli w domyśle, jednakowo odpowiedzialną" (Bonneuil, Fressoz 2020: 188-189), podczas gdy geopolityczne, kulturowe i ekonomiczne asymetrie w tym zakresie wydają się oczywiste. Świadomość pułapek generalizacji i powielania stratyfikacji oraz wtórnych centryzmów obecnych w dyskursywnym uprawomocnianiu epoki człowieka uświadamia potrzebę rozwijania w tym 
polu badawczym refleksyjnych krytyk antropologicznych. Wyrazistą egzemplifikacją tej realnej potrzeby są np. wieloletnie starania Kim Fortun rozwijane w kontekście jej badań osadzonych w późnym industrializmie, by nadać antropologiczny sens problemom środowiskowym i uczynić je uświadomionymi problemami kulturowymi i społecznymi ${ }^{1}$.

Wzajemnych oddziaływań człowieka i bytów pozaludzkich nie sposób pominąć w badaniach na temat antropogenicznych czynników powodujących zmiany klimatyczne, pokazujących, że czerpanie z zasobów naturalnych, tj. jak węgiel, ropa, gaz łupkowy i inne złoża, rozwój przemysłu i rolnictwa wiążą się z wysoką emisją gazów cieplarnianych, $\mathrm{CO} 2$, co w znacznym stopniu wpływa na dewastację środowiska. Procesy te powodują degradację ekosystemów i niszczenie bioróżnorodności, zmieniając przy tym dotychczasowe miejsca życia na planecie w zaburzone krajobrazy i postindustrialne pejzaże. Skutki wzmożonej emisji gazów cieplarnianych, zasolenie mórz i zakwaszanie ziemi, podnoszenie się poziomu oceanów, topnienie lodowców, gwałtowne zjawiska atmosferyczne, powodzie i susze $\mathrm{w}$ różnych miejscach globu czynią z kolei ogromne zmiany w dotychczasowych światach ludzi, powodując istotne zmiany w ich dobrostanie, wymuszając mobilność, powodując problemy ze zdrowiem, sprzyjając bogaceniu się jednej części świata przy jednoczesnej pauperyzacji społeczności żyjących po przeciwnej stronie globu (zob. K. Hastrup, Skrydstrup 2013; F. Hastrup 2014; Eriksen 2016).

1 Badania, jakie prowadzą Kim Fortun i Micke Fortun, koncentrują się na globalnej epidemii astmy, której źródłem jest industrializacja współczesnego świata i jej negatywne skutki środowiskowe, klimatyczne i społeczne. Wspólne wysiłki antropologów, badania empiryczne oraz praca z teorią, sieciowanie działań i kolaboracja badaczy z lekarzami, ekspertami i specjalistami od technologii cyfrowej zaowocowały powstaniem transdyscyplinowego projektu w postaci platformy "The Asthma Files" (TAF), która ma na celu rozwiązywanie problemów związanych ze środowiskowym zdrowiem publicznym na całym świecie. Skupiając się na dużej, globalnej zachorowalności na astmę i inne choroby układu oddechowego, projekt rozwija się zgodnie z potrzebą budowania naukowego, klinicznego i publicznego potencjału zdrowotnego w celu uważnej analizy środowiskowych determinant ludzkiego zdrowia i wypracowania narzędzi analizy stylów myślowych, które kształtują badania naukowe i stanowią podstawę zarządzania środowiskiem. Strona www TAF: https://theasthmafiles.org/ about (pobrano: 01.12.2021). 
Zanurzenie się w świecie więcej-niż-ludzkim wymaga czujności i uważnego poruszania się w sieci dyskursów o zielonej energii, zrównoważonym rozwoju i sprawiedliwości środowiskowej (zob. Sze 2018), by nie przeoczyć wtórnych supremacji, nowych hierarchii i centryzmów, o które nie trudno, gdy badacze i badaczki sytuują siebie w uprzywilejowanej pozycji autorytetu przyjmującego zachodnią, północną, globalną perspektywę postrzegania środowiskowych, materialnych i ekologicznych zależności (Ziser, Sze 2007: 387; Lockyer, Veteto 2013). Przyjęcie strategii poznania, którą można by określić jako podążanie za splotami i asamblażami, jest jeszcze jedną taktyką rozwijaną w ramach polityki wiedzy.

\section{Postantropocentryzm w perspektywach i praktykach antropolo- gicznych}

Rzeczywistość nie jest już postrzegana jako przestrzeń kreowana wyłącznie przez ludzi - podmioty społeczne. Postantropocentryczna perspektywa oraz koncepcja świata więcej-niż-ludzkiego są poddawane naukowym rozważaniom, które testują ich przydatność w wielu kontekstach badawczych. W ramach antropologii coraz wyraźniejszy staje się nurt antropologii energii, w ramach którego rozwijane są teorie i analizy dotyczące energii (jej produkcji, dystrybucji, kontekstów społeczno-kulturowych, ekonomiczno-ekologicznych oraz politycznych) w różnych częściach świata. Dominic Boyer, podkreślając potrzebę wypracowania antropolityki w Antropocenie (2019), analizuje możliwości przeprowadzenia niskoemisyjnej transformacji energetycznej, pytając, co dzieje się w toku tych przemian, jak określone polityki kształtują przyszłość energii niskoemisyjnej oraz jak materialne i infrastrukturalne wymiary energii zarówno umożliwiają, jak i ograniczają możliwość powstania określonych konfiguracji władzy politycznej. W tak zarysowanym kontekście antropolog mówi o zwrocie antyantropocentrycznym (antianthropocentric turn), proponując przeformułowanie antropolityki (anthropolitical) na postantropocentryczne uniwersum konceptualne, w którym antropocentryzm nie może zostać całkowicie odrzucony, 
ponieważ wraz z nim zniknęłaby z pola uwagi ludzka sprawczość i odpowiedzialność za wiele procesów współczesnego świata (Boyer 2019: 4-5). Z kolei Alf Hornborg osadza swoje analizy dotyczące potencjału antropologii w badaniu zjawisk wokół energii w kontekście kapitalizmu i polityki nieograniczonego wzrostu, odkrywając słabości i iluzje myślenia o dekarbonizacji i polityce niskoemisyjności w kontekście dostrojonego proekologicznie kapitalizmu (2019). Harold Wilhite (2016) krytykuje główny nurt zielonej gospodarki i zielonej energii, które przyjmują wzrost gospodarczy za pewnik, ignorując nawyki ukształtowane w materialnym świecie zaprojektowanym i zbudowanym dla wysokiego zużycia energii. Inspirujące są refleksje, diagnozy i prognozy dotyczące przebiegów transformacji energetycznych w różnych kontekstach geograficznych i kulturowych zawarte w tomie Cultures of Energy. Power, Practices, Technologies (Strauss, Rupp, Love 2013). W nurcie antropologii energii poszerzonym o perspektywę etnografii transrelacyjnej od kwietnia 2021 r. prowadzę badania na temat lokalnych sposobów doświadczania kryzysu klimatycznego oraz transformacji energetycznej na obszarze sąsiadującym z kompleksem wydobywczo-energetycznym Turów, uwzględniając transnarodowy polsko-czesko-niemiecki wymiar tych procesów. Zakładam przy tym, że związki środowiska, człowieka, węgla i energii mają charakter głęboko relacyjny, a etnograficzne badania transformacji energetycznej wymagają uznania ekonomicznej, politycznej i kulturowej sprawczości bytów biotycznych i abiotycznych, materii oraz technologii. W takiej ramie konceptualnej analizuję złożony, sporny krajobraz wokół kompleksu Turów, dostrzegając w nim asamblaż wielu działających aktantów w kontekście kryzysu klimatycznego, sprawiedliwej transformacji i projektowanych na tym obszarze przyszłości po węglu.

Jednym z wyrazistych i często przytaczanych przykładów uczynienia z kategorii postantropocentrycznych ram konceptualnych dla praktyk antropologicznych są badania Anne Lowenthaup-Tsing nad relacjami ludzi, grzybów matsutake oraz procesów (późno)kapitalistycznych, do których rozwijania antropolożka potrzebuje nowych perspektyw badawczych, thumacząc: „Muszę zobaczyć, jak łączą się drogi życia i zarazem nieożywione sposoby bycia" (2015: 20). Uwaga badaczki koncentruje się na 
grzybach, które rosną w zniszczonych przez człowieka lasach, upodobawszy sobie zdegradowane biotypy, posiadając zdolność znoszenia ekologicznych bałaganów spowodowanych przez ludzi (2015: 4). Jak wyjaśnia Lowenthaup-Tsing, nie są to jednak rośliny-szkodniki, ,dzięki ich zdolności do odżywiania drzew, matsutake pomagają lasom rosnąć w trudnych warunkach. Podążanie za nimi prowadzi nas do możliwości współistnienia w zaburzeniach środowiska" (2015: 4). Antropolożka nie koncentruje się jednak wyłącznie na wątkach środowiskowych i ekologicznych, a jej badania dotyczą również ,niepewnego życia” i „,niepewnych środowisk” ukazywanych w toku podążania za pozyskiwaniem i handlem matsutake w kontekstach ekologicznych i ekonomicznych.

Sprawczość tych grzybów ujawnia bardzo wyraźnie pęknięcia w globalnej gospodarce, w której stały się pożądanym towarem uprawianym w lasach globalnej Północy i wysyłanym do Japonii i tzw. krajów rozwijających się, a ich niebotyczne ceny, które osiągają w Japonii (kraju, w którym są pożądanym smakołykiem), sprawiają, że matsutake to najcenniejszy grzyb na ziemi. Wielu spośród ich zbieraczy to osoby wywodzące się ze społeczności przesiedlonych i pozbawionych praw obywatelskich mniejszości kulturowych. Tsing podaje przykład zbieraczy na północnym zachodzie Pacyfiku, w Stanach Zjednoczonych, spośród których większość to uchodźcy z Laosu i Kambodży. Funkcjonowanie w procesie zbierania $\mathrm{i}$ handlu matsutake wpływa na ich byt, zapewniając im środki do życia, jednak jest to niepewna praca, która nie daje możliwości otrzymania stałego zatrudnienia, regularnych płac i świadczeń, a zatem ów byt uzależniony jest od ilości zbiorów i obfitości matsutake. Opowiadana przez antropolożkę asamblażowa narracja o matsutake jest jednocześnie „historią ludzkiej kumulacji bogactwa poprzez uczynienie z ludzi i nie-ludzi zasobów do inwestowania" (Lowenthaupt-Tsing 2015: 6), pokazującą, iż natura i społeczeństwo są nierozerwalnie splecione w naszych ciałach, krajobrazach i technologiach.

Warto w tym miejscu wspomnieć o tzw. błękitnej humanistyce, której poświęca się $\mathrm{w}$ rodzimej nauce niewiele uwagi². Jest to dziedzina ,z de-

2 Zagadnieniu niebieskiej humanistyki poświęcony został monograficzny numer „Przeglądu Kulturoznawczego” 2021, nr 2 (48). 
finicji dążącą do zwalczenia ziemskich uprzedzeń w krytycznych perspektywach i metodologiach" (Campbell, Paye 2020: 1). Badania prowadzone w tym nurcie podkreślają sprawczość i materialność oceanów, mórz, jezior, rzek i innych bytów wodnych, pokazując, jak koncepcje przepływu, płynności i mobilności mogą przeciwstawić się strategiom zamknięcia, unieruchomienia i stagnacji konotowanym przez „myślenie lądowe”. „Myślenie przez wodę" i powiązane z tą kategorią metafory konstytuują wyraźne przesunięcie epistemologiczne, projektując kształt rzeczywistości poprzez wodę jako rodzaj otwarcia ontologicznego i wyraźne poszerzenie naukowego poznania o perspektywy oddawane za pomocą opisów stanów wody i praktyk wodnych (zob. Neimanis 2008, 2009; Chen, MacLeod, Neimanis 2013) Ujęcia te sprzyjają wydobywaniu wielorakich relacji splatających losy ludzkie z wodą, strategiami zarządzania hydroenergią i jej zasobami w kontekstach geopolitycznych, społeczno-kulturowych, ekonomicznych i późnokapitalistycznych (DeLoughrey 2019: 26).

Postantropocentryczna perspektywa stanowi ważny element etnografii późnego industrializmu rozwijanej przez przywoływaną już K. Fortun, która $\mathrm{w}$ ramach postulowanej przez siebie etnografii prowadziła m.in. badania wokół katastrofy ekologicznej w indyjskim Bhopalu, który jej zdaniem, nie może być postrzegany jako tradycyjne studium przypadku będące domkniętą przestrzenią analizy. Jak podkreśla Fortun, Bhopal „nie wykazał żadnych dowodów na istnienie granic czasu, przestrzeni czy koncepcji. Bhopal, z którym się zetknęłam, był katastrofą, która uwikłała lokalne i globalne, historyczne i przyszłe, ciągłość i dramatyczne zmiany” (Fortun 2001: 1). „Czerpiąc z długoletnich badań antropologicznych nad doświadczeniem, nauką i polityką toksycznych chemikaliów" antropolożka analizuje dynamikę współczesnego późnego industrializmu - „okresu historycznego charakteryzującego się starzejącą się infrastrukturą przemysłową, krajobrazami usianymi stawami z toksycznymi odpadami, rosnącą zachorowalnością na raka i chorobami przewlekłymi, niestabilnością klimatu, wyczerpaniem paradygmatów i dyscyplin oraz niezwykłym wpleceniem interesów komercyjnych w produkcję wiedzy, decyzje prawne i politykę we wszystkich skalach" (Fortun 2015: 158). Postuluje przy tym rozwijanie etnograficznych porównawczych studiów nad tzw. nagłymi i powolnymi katastrofami, które angażowałyby naukowców, 
ekspertów oraz społeczności lokalne w celu wypracowywania wiedzy dotyczącej relacyjnie ujętych, sprzężonych systemów technologicznych, ekologicznych, społeczno-kulturowych i polityczno-ekonomicznych.

Relacje bytów ludzkich i poza-ludzkich stanowią również oś rozważań cytowanego już A. Hornborga w jego krytycznej analizie powiązań pieniądza, energii i technologii oraz ich związków z Antropocenem. Fundamentalne przewartościowanie relacji tych trzech elementów, które podejmuje antropolog w książce Nature, Society, and Justice in the Anthropocene, polegające na ,podważeniu racjonalistycznych ram, w których toczy się główny nurt rozważań na temat zrównoważonego rozwoju i nierówności” wymaga, jak podkreśla, „uważnej oceny różnych założeń ontologicznych, które leżą u podstaw neoliberalnej ekonomii i inżynierii” (Hornborg 2019: 12). Nie oznacza to jednak, że badacz przyjmuje bez zastrzeżeń perspektywę postantropocentryczną, uznając bezkrytycznie sprawczość bytów poza-ludzkich. Jak wyjaśnia:

Chociaż w pełni zgadzam się z koniecznością stawienia czoła neokolonializmowi i potrzebie zdekonstruowania neoliberalnego rozumienia postępu i rozwoju, poprzez które jest on reprodukowany, muszę odrzucić tak zwane postludzkie propozycje, zgodnie z którymi artefakty, rzeki czy góry - lub w istocie ocieplająca się planeta - posiadają sprawczość. Nie jestem w stanie zaakceptować, że takie nienowoczesne propozycje mogłyby dostarczyć ważnych argumentów, za pomocą których można by politycznie stawić czoła ekologicznej degradacji generowanej przez nowoczesną ekonomię i technologię (Hornborg 2019: 12) .

${ }^{3}$ Ostrze krytyki Hornborga jest zwrócone przede wszystkim przeciwko posthumanistycznym badaczom nauk społecznych, którzy zdaniem antropologa, ,skłonni są wylać dziecko z kąpielą”, odrzucając „kilka fundamentalnych założeń współczesnej nauki, takich jak: analityczne rozróżnienie między ty, co społeczne, a tym, co naturalne, subiektywne, obiektywne oraz semiotyczne i materialne aspekty zjawisk" (2019: 191). Innymi słowy, badacz dostrzega pilną potrzebę przesunięć ontologicznych, ale odrzuca towarzyszącą wielu narracjom posthumanistycznym mglistość i metaforyczność wywodu. Jak pisze: ,jestem tak samo przerażony trwającą destrukcją naszej planety, jak Donna Haraway, Anna Tsing i Bruno Latour, ale mam silne poczucie, że naukowcy przerażeni kłopotami antropocenu mają obowiązek brania odpowiedzialności, która wykracza poza publikowanie mglistych i nieuchwytnych rozważań, które obecnie określa się mianem 'posthumanizmu'” (2019: 193). 
Uprzedzając sprzeciw ze strony posthumanizmów, antropolog przyznaje, że „cele zinternalizowane w żywych organizmach są rzeczywiście produktami ich zewnętrznych relacji, czy to poprzez filogenetyczne, czy ontogenetyczne uczenie się". Uznaje, że celowa sprawczość organizmów „jest rzeczywiście częściowo kształtowana i rozszerzana przez ich aktualne zaangażowanie w inne byty, zarówno ożywione, jak i nieożywione". Podkreśla również, że świadomość, refleksja i intencjonalność nigdy nie są równoznaczne z wiedzą absolutną czy ostateczną, lecz stanowią usytuowaną, częściową i tymczasową reprezentacją warunków pośrednictwa (Hornborg 2019: 181). Zdaniem antropologa, mimo iż w rzeczywistości empirycznej natura i społeczeństwo coraz bardziej się przenikają, to jednak stanowią aspekty, które powinny być analitycznie odrębne, tak, jak odmienne są zjawiska symboliczne i niesymboliczne. Analizując historię powstania kapitalizmu, badacz w unikalnej ludzkiej zdolności do tworzenia abstrakcyjnej reprezentacji upatruje umiejętności niezbędnej do powstania pieniądza, a zatem do zaistnienia rewolucji przemysłowej inaugurującej Antropocen. Jak podkreśla: „ten rachunek odpowiednio integruje historię naszego gatunku z historią kapitału. Zdolności semiotyczne naszego gatunku umożliwiły nam wygenerowanie bezprecedensowych nierówności wewnątrzgatunkowych" (Hornborg 2019: 191). Jednocześnie wyraźnie podkreśla, iż powyższe rozpoznanie nie oznacza, że, choć potencjał kapitalizmu jest wpisany w nasz gatunek, jest on nieuchronnym produktem naszej biologii lub czymś, za co wszyscy jesteśmy wspólnie odpowiedzialni (Hornborg 2019: 191).

\section{W stronę ekologizacji wiedzy}

Wprowadzona wraz z Antropocenem nowa konceptualizacja okresu geologicznego była wywrotowym pomysłem, gdyż ,zaproponowanie ludzkości jako czynnika geologicznego jest przekroczeniem jednej z podstawowych intelektualnych granic nowoczesności" (Moore 2016: 3). Koncepcja epoki ludzkiej sprawczości o konsekwencjach planetarnych wymyka się humanistycznemu myśleniu o usytuowaniu człowieka 
w świecie, inicjując serię jego onto-epistemologicznych przekształceń. Przytoczone powyżej przykłady konceptualnego przeniesienia uwagi z tradycyjnie, a jednocześnie nierzadko esencjalistycznie rozumianych kategorii 'człowiek' i 'społeczeństwo' na ich złożone relacyjne wymiary wiąże się z praktykami, które można by określić mianem ekologizacji wiedzy (ecologisation of knowledge). Polegają one na redefiniowaniu celów i obszarów poznania tak, by z jednej strony, uwzględniały troskę o stan planety i dobrostan ludzi, a z drugiej, umożliwiały dyscyplinowe otwarcie na myślenie post-antropocentryczne i sprawczość bytów poza-ludzkich. Jednocześnie wspomniane praktyki stanowią wyraz dyscyplinowej odpowiedzialności wynikającej z diagnozowania uwarunkowań i konsekwencji postępującego kryzysu klimatycznego i powiązanych z nim przemian ekonomiczno-społecznych, dewastacją środowiska i ekosystemów, zanikiem bioróżnorodności. Z ekologizacją wiedzy łączy się również gotowość do uznania, iż perspektywy badawcze, propozycje teoretyczne oraz kategorie analityczne wypracowywane w ramach dyscypliny stanowią rezultat jej poszukiwania słowników, metod i narzędzi badawczych pozwalających na analizę współczesnych ludzko-nie-ludzkich zjawisk i ich dyskursywną wykładnię.

Uważnej, wnikliwej analizy wymaga koncepcja Antropocenu i przecinające się w tym dyskursywnym polu kategorie, idee i teorie, gdyż jest to bardzo pojemna konstrukcja, której rozmaite konceptualizacje odzwierciedlają to, czyje głosy mają znaczenie, jakie pozycje geopolityczne i społeczne są uprzywilejowane i jak dystrybuowana jest (nie)sprawiedliwość środowiskowa. Warte uważnej obserwacji są praktyki łączenia kapitału, władzy i zasobów - elementów współwystępujących w procesach eksploatacji surowców oraz rozwijania energopolityk (energypower) (Boyer 2019) w kontekstach lokalnych i globalnych, co znajduje wyraz w wiązaniu Antropocenu z epoką Kapitalocenu (Moore 2016), kierując uwagę badawczą na konkretne praktyki i powiązania kapitału, władzy i zasobów na przecięciu lokalnego z globalnym. Kategoria świata więcej-niż-ludzkiego nie obejmuje przy tym wyłącznie bytów biologicznych i materialnych, lecz także podlegające przyspieszonym zmianom obszary życia społecznego budowane w relacjach ludzi-środowiska-kapitału-technologii 
i przemysłu. Proces ekologizacji wiedzy można by postrzegać również w kategoriach kontrhegemonicznych praktyk odzyskiwania perspektyw i stylów badawczych będących krytykami dominujących, neoliberalnie skrojonych strategii rozwijania wiedzy, które jako:

(...) misterny splot narracji składających się na kulturę i tożsamość współczesnego człowieka, są ściśle zorientowane na antropocentryzm i przesiąknięte wyjątkowością ludzkiego charakteru do tego stopnia, że wartości i dramaty nie-ludzkich dziejów są marginalizowane lub trywializowane. Co więcej, społeczno-ekonomiczne struktury nowoczesnej/zachodniej podmiotowości, widoczne w ideach jednostki, rodziny i państwa narodowego, są uwarunkowane narracjami o autorealizacji i materialnym sukcesie, ograniczając zdolność przyznania się do ekologicznej porażki, do zaangażowania się w działania społeczne, a nawet do rozpoznania towarzyszącego im żalu spowodowanego ekologiczną degradacją (Jones, Rigby, Williams 2020: 395).

Przyjęcie antropologicznej perspektywy, kierującej uwagę badacza i badaczki na zależności i powiązania wielu sprawczych aktantów, procesów i zjawisk pozwala na nieprzeoczenie aspektów wyciszanych w neoliberalnych dyskursach sukcesu (zob. Faber 2018: 8-28). Jest to zatem nie tylko koncepcja poznawcza, lecz także krytycznie sprofilowany projekt etyczny i polityczny, który w toku koncentracji uwagi na środowiskowych kontekstach złożonych procesów związanych z Antropocenem, Kapitalocenem, zdrowiem środowiskowym (Fortun 2016), wzrostem, dewzrostem (D’Alisa, Demaria, Kallis 2020) daje szansę na pogłębione analizy wielu aktualnych procesów i zjawisk rozgrywających się na przecięciu kulturowego, społecznego, środowiskowego, materialnego, ekologicznego i technologicznego.

Krytyczne perspektywy antropologiczne mogą przyczynić się do oświetlania nieoczywistych aspektów ustanowienia epoki antropogenicznych przeobrażeń świata i środowiska. W ich domenach zachodzą lokalne procesy pod wpływem powtarzalnych mechanizmów globalnych, takie jak dewastacja środowiska, deforestacja, wzrost skażenia gleby, wody 
i powietrza (Connell 2020: 218-235); zmiany w dobrostanie ludzi, bogacenie się i pauperyzacja, migracje; industrializacja i antropogeniczne zmiany krajobrazów oraz wiele innych. Wszystkie one generują określone procesy, które wpływają zarówno na życie społeczne, jak i kulturowe, ucząc ludzi tego, co Kim Fortun określa mianem środowiskowego sensu (environmental sense) zmieniającego sposoby myślenia i praktyki działania (Fortun 2016: 5). Rozwijanie i wzmacnianie widoczności antropologicznych krytyk polityk i praktyk wpisanych w te pola badawcze jest potrzebne zarówno $\mathrm{w}$ ramach akademii, jak i w pozaakademickich kręgach społecznych zgodnie z założeniem, iż ekologiczna odpowiedzialność nauki wiąże się z kształtowaniem wyobraźni społecznej na temat tych przyczyn, przebiegów i konsekwencji tych procesów dla świata więcej-niż-społecznego.

Ekologizacja antropologii może być także postrzegana jako odpowiedź na, mówiąc za Thomasem Eriksenem, przegrzanie świata (overheated world) (Eriksen 2016). Utworzona przez antropologa metafora wbrew nasuwającym się skojarzeniom, nie odnosi się wyłącznie do wzrostu temperatury na Ziemi, ale przede wszystkim nawiązuje do szybkości, „Z jaką zachodzą zmiany gospodarcze, środowiskowe i społeczne, a także do powszechnego przekonania, że zmiany te wymykają się spod ludzkiej kontroli, powodując szeroki zakres niezamierzonych długoterminowych konsekwencji o nieprzewidywalnych, często szkodliwych dla życia na Ziemi, skutkach" (Stensrud, Eriksen 2019: 1).

Świadomość zarysowanych powyżej wyzwań wiąże się z koniecznością przemyślenia dotychczasowych celów, strategii poznania i trybów wytwarzania akademickiej wiedzy. Jeśli bowiem zgodnie z założeniami ekologizacji wiedzy zgodzimy się na fronetyczną odpowiedzialność nauki w życiu społecznym i poza-ludzkim, akceptujemy fakt, że „(...) analiza otaczającej nas rzeczywistości to nie tylko działalność akademicka, to także uczestnictwo w kulturze, współtworzenie demos, również rozumianego w wersji poszerzonej, tak, jak ujmowane jest to w optyce posthumanistycznej, po zwrocie ontologicznym" (Nowak 2016: 109). W procesie ekologizacji istotne jest uznanie różnych podmiotów w relacjach powstawania wiedzy, jak i krytyczna analiza zastanych hierarchii sprawczych 
czynników i przekonań dotyczących obiegów i dystrybucji wiedzy o rzeczywistości. Z tym niełatwym zadaniem wiąże się potrzeba podjęcia próby ponownego namysłu nad pojęciem naukowości, eksperckości, autorytetu naukowego, a także relacji między nauką, środowiskiem, sektorem usług, nowymi technologiami, polityką i społeczeństwem (Feenberg, Callon 2010), o co wielokrotnie upominał się w dyscyplinie Paul Rabinow, rozwijając swój projekt laboratorium współczesności w ramach antropologii aktualnego (2007; 2011). Rzeczywistości więcej-niż-społecznej potrzebne są antropologiczne, odpowiedzialne ekologicznie interwencje, otwarte na aktualne zjawiska i problemy świata. Być może dzięki tej transformacji antropologia nie utraci szansy nie tylko na prognozowanie przyszłości społeczeństw, lecz także na współtworzenie wiedzy naukowej antycypującej i wyjaśniającej jej kształty.

\section{Bibliografia}

Archer M. (2013). Człowieczeństwo. Problem sprawstwa. przeł. A. Dziuban. Kraków: Zakład Wydawniczy „Nomos”.

Bakke M. (2000). Gdy stawka jest większa niż życie. Sztuka wobec mineralno-biologicznych wspólnot. Teksty Drugie,1, 165-185.

Barad K. (2003). Posthumanist Performativity: Toward and Understanding of How Matter Comes to Matter. Signs: Journal of Women in Culture and Society, 28, 801-831.

Bastian M. (2017). Towards a More-Than-Human Participatory Research. W: M. Bastian, O. Jones, N. Moore, E. Roe (red.), Participatory Research in More-than-human-word (s. 17-37). London-New York: Routledge.

Bastian M., Owain J., Moore N., Roe E. (2017). Introduction. More-thanhuman Participatory. Contexts, Challenges, Possibilities. W: M. Bastian, O. Jones, N. Moore, E. Roe (red.), Participatory Research in MoreThan-Human-Word (s. 1-16). London-New York: Routledge. 
Bińczyk E. (2018). Utrata przyszłości w epoce antropocenu, Stan Rzeczy, 14 (1), 109-134.

Bombik M. (2020). The Bases and Methodology of Deep Ecology. Studia Ecologiae et Bioethicae, 18 (5), 67-85.

Bonneuil Ch., Fressoz J-B. (2020). Antropocen czy oligantropocen? przeł. P. Śniedziewski. Teksty Drugie, 1, 186-203.

Boyer, D. (2019). Energopolitics: Wind and Power in The Anthropocene. Durham, N.C.: Duke University Press.

Braidotti R. (2014). Working Towards The Posthumanities, TransHumanities, 7 (1), 155-176.

Braidotti R. (2018). Posthuman Critical Theory. W: R. Braidotti, M. Hlavajova (eds.), Posthuman glossary (s. 339-341). London, Oxford, New York: Bloomsbury Academic.

Buell L. (1995). The Environmental Imagination: Tho.reau, Nature Writing, and The Formation of American Culture. Cambridge: Harvard University Press.

Campbell A. Paye M. (2020). Water Enclosure and World-Literature: New Perspectives on Hydro-Power and World-Ecology. Humanities, 9 (106), 1-15.

Castree, N. (2008). Neoliberalising Nature: The Logics of Deregulation and Reregulation. Environment and Planning A, 40 (2), 131-152

Chen C., MacLeod J., Neimanis A. (2013). Thinking with Water. Montreal: McGill-Queen's University Press.

Colebrook C. (2015). Who Comes After The Post-Human?. W: J. Roffe, H. Stark (red.), Deleuze and The Non/Human (s. 217-234). New York: Palgrave Macmillan.

Colebrook C. (2017). "We Have Always Been Post-Anthropocene: The Anthropocene Counter-Factual." W: R. Grusin (red.), Anthropocene Feminisms (s. 1-20). Minneapolis: University of Minnesota Press.

Connell R. (2020). Maroon Ecology: Land, Sovereignty, and Environmental Justice. The Journal of Latin American and Caribbean Anthropology, 25 (2), $218-235$.

Connolly J., Prothero A. (2008). Green Consumption: Life Politics, Risk and Contradictions. Journal of Consumer Culturev 8 (1), 117-146. 
Crutzen, P.J., Stoermer, E.F. (2000). The "Anthropocene”. Global Change Newsletter, 41 (17), 17-18.

D’Alisa G., Demaria F., Kallis G. (2020). Dewzrost: słownik nowej ery, Łódź: Langel-Łucja Lange.

Deleuze G. (2001). Empiricism and Subjectivity. An Essay on Hume's Theory of Human Nature. New York: Columbia University Press.

DeLoughrey E. (2019). Toward a critical ocean studies for the Anthropocene. English Language Notes, 57, 21-36.

Dolphijn R., Van der Tuin I. (2018). Wywiad z Karen Barad. W: R. Dolphijn, I. Van der Tuin (red.), Nowy materializm. Wywiady i kartografie, przeł. J. Bednarek, J. Maliński, Gdańsk-Poznań-Warszawa: Fundacja Machina Myśli.

Domańska E. (2007). Zwrot performatywny we współczesnej humanistyce. Teksty Drugie, 5, 48-61.

Dove M. (2014). The Anthropology of Climate Change. An Historical Reader. Wiley-Blackwell: Malden (MA).

Duit,A. (2016). The Four Faces of The Environmental State: Environmental Governance Regimes in 28 Countries. Environmental Politics, 25 (1), 69-91.

Eriksen T. H. (2016). Overheating: An Anthropology of Accelerated Change. London: Pluto Press.

Eriksen T. H. Stensrud S. B. (red.) (2019). Climate, Capitalisme and Communities. An Anthropology of Environmental Overheating. London: Pluto Press.

Evans, D., Abrahamse W. (2009). Beyond Rhetoric: The Possibilities of and for "Sustainable Lifestyles". Environmental Politics, 18 (4), 486502.

Faber D. (2018). Global Capitalism, Reactionary Neoliberalism, and the Deepening of Environmental Injustices. Capitalism, Nature, Socialism, 29 (2), 8-28.

Feenberg A., Callon M. (2010). Between reason and experience: essays in technology and modernity. London: The MIT Press. 
Ferrando F. (2016a). Posthumanizm, transhumanizm, antyhumanizm, metahumanizm oraz nowy materializm. Różnice i relacje, Rocznik Lubuski, 42 (2) 13-26.

Ferrando F. (2016b). Humans Have Always Been Posthuman: A Spiritual Genealogy of the Posthuman. W: D. Banerji, M.R. Paranjape (red.), Critical Posthumanism and Planetary Futures (s. 243-256). New Delhi: Springer.

Fortun K. (2015). Figuring Out Theory. Ethnography Scetches. W: D. Boyer, J.D. Faubion, G.E. Marcus (red.), Theory Can Be More than It Used to Be (s. 147-167). Ithaca, London: Cornell University Press.

Fortun K. (2001). Advocacy After Bhophal: Environmentalism, Disaster, New Global Orders. Chicago: The Universitety of Chicago Press.

Fortun K. (2016). Anthropology in Farm Safety. Journal of Agromedicine, $22(1), 1-8$.

Haraway D. (2012). Manifest gatunków stowarzyszonych, przeł. J. Bednarek. W: A. Gajewska (red.), Teorie wywrotowe. Antologia przekładów (s. 241-260). Poznań: Wydawnictwo Poznańskie.

Haraway D. (2016). Staying With The Trouble: Anthropocene, Capitalocene, Chthulucene. W: J.W. Moore (red.), Anthropocene or capitalocene?: Nature, History, and The Crisis of Capitalism (s. 3476). Oakland: CA: PM Press.

Haraway, D. (2015). Anthropocene, Capitalocene, Plantitionocene, Chthulucene: Making Kin. Environmental Humanities, 6, 159-165.

Hastrup F. (2014). Qualifying Coastal Nature. Bio-conservation Projects in South East India. W: K. Hastrup (red.), Anthropology and Nature (s. 43-61). London, New York: Routledge.

Hastrup K. (2007). Agency, Anticipation and Creativity. W: E. Hallam, T. Ingold (red.), Creativity and Cultural Improvisation (s. 193-206). Oksford, New York: Berg.

Hastrup K., (red.) (2014). Anthropology and Nature. London, New York: Routledge.

Hastrup K., Skrydstrup M. (eds.) (2013). The Social Life of Climat Change. Models: Anticipating Nature. London: Routledge. 
Hayward T. (1997). Anthropocentrism: A Misunderstood Problem. Environmental Values 6 (1), 49-63.

Holbraad M., Pedersen M. A. (2017). The Ontological Turn. An Anthropological Exposition. Cambridge: Cambridge University Press.

Hornborg A. (2019). Nature, Society and Justice in the Anthropocene. Unraveling the Money- Energy-Technology Complex. Cambridge: Cambridge University Press.

Howe, C. (2019). Ecologics: Wind and Power in The Anthropocene. Durham, N.C.: Duke University Press.

Ingold T. (2000). The Perception of the Environment. Essays on Livelihood, Dwelling, and Skill. London, New York: Routledge.

Ingold T.(2013). Making: Anthropology, Archaeology, Artand Architecture. London: Routledge.

Knorr-Cetina K. (1981). The Manufacture of Knowledge. An Essay on The Constructivist and Contextual Nature of Science. Oxford, New York: Pergamon Press.

Kohn E. (2013). How Dogs Dream: Amazonian Natures and The Politics of Transspecies Engagement. American Ethnologist, 34 (1), 3-24.

Latour B. (2010). Splatajac na nowo to, co społeczne. Wprowadzenie do teorii aktora sieci, przeł. K. Arbiszewski, A. Derra. Kraków: Wydawnictwo Universitas.

Latour B., Woolgar S. (2020). Życie laboratoryjne. Konstruowanie faktów naukowych, przeł. K. Arbiszewski, P. Gąska, M. Smoczyński, A. Zabielski. Warszawa: Narodowe Centrum Kultury.

Lockyer J., Veteto J. R. (2013). Environmental Anthropology Engaging Ecotopia: An Introduction. W: J. Lockyer, J.R. Veteto (red.), Environmental Anthropology Engaging Ecotopia. Bioregionalism, Permaculture, and Ecovillages (s. 1-34). London: Berghahn Books.

Lowenthaup-Tsing A. (2015). The Mushroom at The End of The World: On The Possibility of Life in Capitalist Ruins. Princeton: Princeton University Press.

Majbroda K. (2019). W relacjach, sieciach, splotach asamblaży. Wyobraźnia antropologii społeczno-kulturowej wobec aktualnego. Wrocław: Oficyna Wydawnicza Atut. 
Majbroda K. (red.) (2021a). Etnografia transrelacyjna. Poznanie i praxis $w$ świecie ludzi i bytów poza-ludzkich. Wrocław: Katedra Etnologii i Antropologii Kulturowej UWr.

Majbroda K. (2021b). W stronę etnografii transrelacyjnej. Antropologia wobec Antropocenu, kryzysu klimatycznego i relacyjnie urządzonej rzeczywistości, Etnografia Polska 65, 5-26.

McCarthy J., Prudham S. (2004). Neoliberal Nature and Nature of Neoliberalism. Geoforum 35, 275-283.

Moore J. W. (ed.) (2016). Anthropocene or Capitalocene? Nature, History and The Crisis of Capitalism, Oakland: PM Press.

Moszyński K. (1958). Człowiek wstęp do etnografii powszechnej i etnologii, Wrocław: Zakład Narody im. Ossolińskich.

NeimanisA.(2008).Bodies ofWater.Human Rights and theHydrocommons, Topia. Canadian Journal of Cultural Studies,21,161-182.

Neimanis A. (2009). We Are All Bodies of Water, Alphabet City: Water. MIT Press.

Nowak A.W. (2016). Wyobraźnia ontologiczna. Filozoficzna (re)konstrukcja fronetycznych nauk społecznych. Warszawa: Instytut Badań Literackich PAN/Wydawnictwo Naukowe UAM.

Owain J., Rigby K., Williams L. (2020). Everyday Ecocide, Toxic Dwelling, and The Inability To Mourn. Environmental Humanities, 12 (1), 388-405.

Penty A.J. (1922). Post-industrialism. New York: Macmillan.

Pepperell R. (2005). The Posthuman Manifesto. Kritikos, 2, 10-11.

Puig de la Bellacasa M. (2017). Matters of Care: Speculative Ethics in More Than Human Worlds. Minneapolis: University of Minnesota Press

Pyyhtinen O. (2016). More-Than-Human Sociology: A New Sociological Imagination. London: Palgrave Pivot.

Rabinow P. (2007). Marking Time. On the Anthropology of the Contemporary. Princeton, Oxford: Princeton University Press.

Rabinow P. (2011). The Accompaniment. Assembling The Contemporary. Chicago, London: University of Chicago Press. 
Rewers E. (2017). Humanistyka wobec koncepcji „kulturynatury”. Teksty Drugie 1, 163-175.

Roffe J., Stark H. (red.) (2005).Deleuze and The Non/Human. London: Palgrave Macmillan.

Roffe J., Stark H. (2015). Deleuze and The Nonhuman Turn: An Interview with Elizabeth Grosz, in: Roffe J., Stark H. (red.), Deleuze and The Non/Human (s.17-24). London: Palgrave Macmillan.

Schatzki T. (2002). The Site of The Social: A Philosophical Account of The Constitution of Social Life and Change, Pennsylvania: Pennsylvania State University Press.

Serres M. (1992). Le contract naturel. Paris: Flammarion.

Smith J., Hige M.M. (2017). Exploring the Anthropology of Energy: Ethnography, Energy and Ethic, Energy Research\&Social Science 30, $1-6$.

Srivastav, A. (2019). The Science and Impact of Climat Change. Singapor: Splinger.

Steger T. (2007). Making The Case for Environmental Justice in Central \&Eastern Europe. Budapest: CEU Center for Environmental Policy and Law.

Strauss S., Rupp S., Love T. (red.) (2013). Cultures of Energy: Power, Practices, Technologies. Walnut Creek: Left Coast Press.

Suchman L. (2007). Human-Machine Reconfigurations: Plans and Situated Actions. Cambridge University Press, Cambridge.

Sze J. (2018). Sustainability: Approaches to Environmental Justice and Social Power. New York: New York University Press.

Tomicki R., Tomicka J. (1975). Drzewo życia. Ludowa wizja świata i człowieka. Warszawa: Ludowa spółdzielnia wydawnicza.

Wilhite H. (2016). The Political Economy of Low Carbon Transformation. Braking of Habits on Capitalism. London: Routledge.

Yusoff K., Gabrys J. (2011). Climate Change and the Imagination. Wiley Interdisciplinary Reviews: Climate Change 2 (4), 516-534.

Ziser M., Sze J. (2007). Climate Change, Environmental Esthetics, and Global Environmental Justice. Cultural Studies. Discourse, 29 (2-3), 384-410. 